\title{
FINGER PAINTING BERPENGARUH TERHADAP PERKEMBANGAN MOTORIK HALUS ANAK MENGGUNAKAN DENVER II PADA ANAK USIA 3-5 TAHUN DI YAYASAN PUTERI SION MEDAN
}

\author{
Tiurlan Mariasima Doloksaribu \\ Jurusan Keperawatan Poltekkes Kemenkes Medan
}

\begin{abstract}
Abstrak
Finger painting adalah kegiatan melukis dengan jari untuk melatih kemampuan otot tangan dan jari serta untuk melatih daya imajinasi anak. Tujuan penelitian untuk mengetahui pengaruh finger painting terhadap kemampuan motorik halus pada anak usia 3-5 tahun di Yayasan Puteri Sion Medan.Jenis dan desain penelitian yang digunakan adalah quasi eksperimen (eksperimen semu)dengan rancangan penelitian one grouppretest-posttest design. Alat yang digunakan dalam pengumpulan data adalah lembar ceklis Denver II dan peralatan seperti kubus 8 buah, pensil, kertas gambar dll sedangkan alat untuk intervensi finger paintingmenggunakan pewarna, pensil, kertas gambar, air, dan tissue. Populasi penelitian adalah anak usia 35 tahun yang merupakan murid di Yayasan Puteri Sion Medan. Sampel diambil dengan teknik total sampling sebanyak 19 orang anak. Hasil uji statistik t-test menunjukkan peningkatan kemampuan motorik halus sebelum dan setelah dilakukan intervensi finger painting yaitu 0,004 dengan tingkat kemaknaan $\mathrm{p}<0,05$. Kesimpulan penelitian ini menunjukkan terjadi peningkatan kemampuan motorik halus anak umur 3-5 tahun di Yayasan Puteri Sion Medan sebesar 0,29 kali lebih baik setelah dilakukan intervensi finger painting.Diharapkan guru-guru memberikan finger paintingsebagai salah satu kegiatan bermain pada anak umur 3-5 tahun di Yayasan Puteri Sion Medan.
\end{abstract}

Kata kunci : Finger Painting, Motorik Halus

\section{PENDAHULUAN}

Finger painting adalah kegiatan melukis dengan jari untuk melatih perkembangan otot tangan dan jari serta melatih daya imajinasi anak (Pramita, dkk (2015). Finger painting merupakan teknik melukis dengan mengoleskan pewarna pada kertas dengan jari jemari atau telapak tangan (Solahudin, 2008).Perkembangan adalah bertambahnya kemampuan dalam struktur dan fungsi tubuh yang lebih kompleks dalam pola yang teratur sebagai hasil dari proses pematangan (Soetjiningsih, 2015).

Cahyaningsih (2014) Tahapan perkembangan anak : Neonatus (0-28 hari), bayi (1-12 bulan), Toodler (1-3 tahun), Pra sekolah (4-6 tahun), Sekolah 7-13 tahun), Remaja (14-18 tahun). Nursalam (2008), anakusia 3-5 tahun berada pada fase inisiatif vs rasa bersalah, pada masa ini rasa ingin tahu dan daya imajinasi anak berkembang sehingga anak banyak bertanya mengenai segala sesuatu disekelilingnya yang tidak diketahuinya.Pada Usia 3-5 tahun anak mulai mengenal cita-cita, belajar menggambar, menulis, dan mengenal angka serta bentuk/warna benda.

Motorik halus adalah aspek yang berhubungan dengan kemampuan anak untuk mengamati sesuatu, melakukan gerakan yang melibatkan bagian-bagian tubuh tertentu yang dilakukan otot-otot kecil tetapi melakukan koordinasi yang cermat, misalnya kemampuan untuk menggambar, memegang sesuatu benda (Maryunani,
2010). Finger paintinguntuk melatih gerakan otot jari jemari, mengkoordinasikan mata, mengekspresikan diri dengan berkarya seni (Astria, 2015).PenelitianAskandari (2013) dilakukan dalam 2 siklus dan setiap siklus terdapat 3 pertemuan yakni: pada siklus 1 pertemuan 1; kemampuan anak dalam mengulas cat sebesar 33\% dan pada siklus ke 1 pertemuan ke 2; sebesar 40\%, pada siklus 1 pertemuan ke 3; meningkat 46,5\% dan pada siklus ke 2 pertemuan 1 ; meningkat sebesar $53,5 \%$, pada siklus ke 2 pertemuan ke 2; meningkat sebesar meningkat sebesar 67\% dan pada siklus ke 2 pertemuan 3; meningkat 73,3\%. Hasil penelitian tersebut mengatakan bahwa finger paintingdapat meningkatkan kemampuan motorik halus pada anak di Taman Kanak-Kanak Mutiara Sungai Kakap Kabupaten Kubu Raya tahun 2013. Vitamami(2012) mengatakan bahwa sebanyak 80\% anak RA Babussalam Krian Sidoarjo mengalami peningkatankemampuan motorik halus setelah dilakukan finger paintingselama 2 siklus dimana setiap siklus dilakukan dua pertemuan.

\section{METODE PENELITIAN}

Jenis dan desain penelitian adalah quasi eksperimen (eksperimen semu)dengan rancangan penelitian one grouppretest-posttest (Notoatmodjo, 2016), untuk menganalisis perbedaan kemampuan motorik halus anak sebelum dan setelah dilakukan finger painting. Penelitian dilaksanakan di Yayasan Puteri Sion mulai 
bulan Januarisampai Juni 2017 dengan populasi seluruh anak berusia 3-5 tahun di Yayasan Puteri Sion Medan yang

berjumlah 19 orang, atautotal sampling.

\section{HASIL PENELITIAN}

Tabel 1. Distribusi Frekuensi Kemampuan Motorik Halus berdasarkan Usia Gestasi di Yayasan Puteri Sion Medan Tahun 2017

\begin{tabular}{|c|c|c|c|c|c|c|c|c|c|c|c|c|}
\hline \multirow{3}{*}{ Usia Gestasi } & \multicolumn{10}{|c|}{ Kemampuan Motorik Halus } & \multirow{2}{*}{\multicolumn{2}{|c|}{ Total }} \\
\hline & \multicolumn{2}{|c|}{ Lebih } & \multicolumn{2}{|c|}{ Normal } & \multicolumn{2}{|c|}{ Peringatan } & \multicolumn{2}{|c|}{ Keterlambatan } & \multicolumn{2}{|c|}{ TAK } & & \\
\hline & $\mathrm{n}$ & $\%$ & $\mathrm{n}$ & $\%$ & $\mathrm{n}$ & $\%$ & $\mathrm{n}$ & $\%$ & $\mathrm{n}$ & $\%$ & $\mathrm{n}$ & $\%$ \\
\hline <37 minggu & 0 & 0 & 0 & 0 & 1 & 5.3 & 0 & 0 & 0 & 0 & 1 & 5.3 \\
\hline 37-42 minggu & 1 & 5.3 & 7 & 37.1 & 4 & 21.2 & 1 & 5.3 & 2 & 10.5 & 15 & 78.9 \\
\hline$>42$ minggu & 0 & 0 & 2 & 10.5 & 0 & 0 & 1 & 5.3 & 0 & 0 & 3 & 15.8 \\
\hline Total & 1 & 5.3 & 9 & 47.4 & 5 & 26.5 & 2 & 10.5 & 2 & 10.5 & 19 & 100 \\
\hline
\end{tabular}

Berdasarkan usia gestasi mayoritas responden pada kelompok usia gestasi 37-42 minggu pada sebanyak 15 anak (78.9\%), 1 anak dengan usia gestasi $<37$ minggu (5.3\%), dan 3 anak (15.8\%) pada usia gestasi $>42$ minggu

Tabel 2 Distribusi Frekuensi Kemampuan Motorik Halus berdasarkan Umur di Yayasan Puteri Sion Medan Tahun 2017

\begin{tabular}{|c|c|c|c|c|c|c|c|c|c|c|c|}
\hline \multirow{3}{*}{$\begin{array}{l}\text { Umur } \\
\text { Kronologis }\end{array}$} & \multirow{3}{*}{$\begin{array}{c}\text { Umur } \\
\text { perkembangan }\end{array}$} & \multicolumn{10}{|c|}{ Kemampuan Motorik Halus } \\
\hline & & \multicolumn{2}{|c|}{ Lebih } & \multicolumn{2}{|c|}{ Normal } & \multicolumn{2}{|c|}{ Peringatan } & \multicolumn{2}{|c|}{ Keterlambatan } & \multicolumn{2}{|c|}{ TAK } \\
\hline & & $\mathrm{n}$ & $\%$ & $\mathrm{n}$ & $\%$ & $\mathrm{n}$ & $\%$ & $\mathrm{n}$ & $\%$ & $\mathrm{n}$ & $\%$ \\
\hline 3 tahun 2 bulan & 3 tahun 0 bulan & 0 & 0 & 1 & 5.3 & 0 & 0 & 0 & 0 & 0 & 0 \\
\hline 3 tahun 4 bulan & 3 tahun 3 bulan & 0 & 0 & 1 & 5.3 & 2 & 10.5 & 0 & 0 & 0 & 0 \\
\hline 3 tahun 7 bulan & 3 tahun 6 bulan & 0 & 0 & 0 & 0 & 1 & 5.3 & 0 & 0 & 0 & 0 \\
\hline 4 tahun 1 bulan & 4 tahun 0 bulan & 0 & 0 & 1 & 5.3 & 2 & 10.5 & 1 & 5,3 & 0 & 0 \\
\hline 4 tahun 3 bulan & 4 tahun 3 bulan & 0 & 0 & 3 & 15.9 & 0 & 0 & 0 & 0 & 1 & 5.3 \\
\hline 4 tahun 7 bulan & 4 tahun 6 bulan & 1 & 5.3 & 1 & 5.3 & 0 & 0 & 0 & 0 & 1 & 5.3 \\
\hline 4 tahun 9 bulan & 4 tahun 9 bulan & 0 & 0 & 2 & 10.5 & 0 & 0 & 0 & 0 & 0 & 0 \\
\hline \multirow[t]{2}{*}{5 tahun 0 bulan } & 5 tahun 0 bulan & 0 & 0 & 0 & 0 & 0 & 0 & 1 & 5.3 & 0 & 0 \\
\hline & Total & 1 & 5.3 & 9 & 47.5 & 5 & 26.4 & 2 & 10.5 & 2 & 10.5 \\
\hline
\end{tabular}

Berdasarkan tabel diatas,terdapat1 responden (5.3\%) umur 4 tahun 3 bulan dan 1 responden (5.3\%) umur 4 tahun 6 bulan memiliki kemampuan motorik halus pada kelompok keterlambatan.

Mayoritas responden berada pada kelompok umur 4 tahun 3 bulan dengan kemampuan motorik halus normal sebanyak 3 responden (15.9\%). Pada kelompok umur 4 tahun 6 bulan terdapat 1 responden (5.3\%) memiliki kemampuan motorik halus lebih.

Tabel 3. Distribusi Frekuensi Kemampuan Motorik Halusberdasarkan Jenis Kelaminsebelumdilakukan finger painting di Yayasan Puteri Sion Medan Tahun 2017

\begin{tabular}{|c|c|c|c|c|c|c|c|c|c|c|c|c|}
\hline \multirow{3}{*}{ Jenis kelamin } & \multicolumn{10}{|c|}{ Kemampuan Motorik Halus } & \multirow{2}{*}{\multicolumn{2}{|c|}{ Total }} \\
\hline & \multicolumn{2}{|c|}{ Lebih } & \multicolumn{2}{|c|}{ Normal } & \multicolumn{2}{|c|}{ Peringatan } & \multicolumn{2}{|c|}{ Keterlambatan } & \multicolumn{2}{|c|}{ TAK } & & \\
\hline & $\mathrm{n}$ & $\%$ & $\mathrm{n}$ & $\%$ & $\mathrm{n}$ & $\%$ & $\mathrm{n}$ & $\%$ & $\mathrm{n}$ & $\%$ & $\mathrm{~N}$ & $\%$ \\
\hline Laki-laki & 1 & 5.3 & 6 & 31.6 & 1 & 5.3 & 0 & 0 & 1 & 5.3 & 9 & 47.4 \\
\hline Perempuan & 0 & 0 & 3 & 15.8 & 4 & 21.1 & 2 & 10.5 & 1 & 5.3 & 10 & 52.6 \\
\hline Total & 1 & 5.3 & 9 & 47.4 & 5 & 26.3 & 2 & 10.5 & 2 & 10.5 & 19 & 100 \\
\hline
\end{tabular}

Dari 19 responden, dari 9 responden berjenis kelamin laki-laki mayoritas 6 responden (31.6\%) memiliki kemampuan motorik halus normal dan dari 10 responden berjenis kelamin perempuan mayoritas memiliki kemampuan motorik halus peringatan sebanyak 4 responden (21.1\%). Terdapat 1 responden (5.3\%) berjenis kelamin laki-laki dengan kemampuan motorik halus lebih sedangkan sebanyak 2 responden perempuan (10.5\%) memiliki kemampuan motorik halus keterlambatan. 
Tabel 4 Distribusi Frekuensi Kemampuan Motorik Halusberdasarkan Jenis Kelamin setelah dilakukan finger painting di Yayasan Puteri Sion Medan Tahun 2017

\begin{tabular}{|c|c|c|c|c|c|c|c|c|c|c|c|c|}
\hline \multirow{3}{*}{ Jenis kelamin } & \multicolumn{10}{|c|}{ Kemampuan bahasa post tes } & \multirow{2}{*}{\multicolumn{2}{|c|}{ Total }} \\
\hline & \multicolumn{2}{|c|}{ Lebih } & \multicolumn{2}{|c|}{ Normal } & \multicolumn{2}{|c|}{ Peringatan } & \multicolumn{2}{|c|}{ Keterlambatan } & \multicolumn{2}{|c|}{ TAK } & & \\
\hline & $\mathrm{n}$ & $\%$ & $\mathrm{n}$ & $\%$ & $\mathrm{n}$ & $\%$ & $\mathrm{n}$ & $\%$ & $\mathrm{n}$ & $\%$ & $\mathrm{~N}$ & $\%$ \\
\hline laki-laki & 7 & 36.8 & 1 & 5.3 & 0 & 0 & 0 & 0 & 1 & 5.3 & 9 & 47.4 \\
\hline Perempuan & 4 & 21.1 & 5 & 26.3 & 0 & 0 & 0 & 0 & 1 & 5.3 & 10 & 52.6 \\
\hline Total & 11 & 57.9 & 6 & 31.6 & 0 & 0 & 0 & 0 & 2 & 10.5 & 19 & 100 \\
\hline
\end{tabular}

Setelah dilakukan finger painting sebanyak 7 responden laki-laki (36.8\%) memiliki kemampuan motorik halus lebih sedangkan pada responden perempuan, 4 responden (21.1\%) memiliki kemampuan meotorik halus lebih dan 5 responden (26.3\%) dengan kemampuan motorik halus normal.

Tabel 5 Distribusi Frekuensi Kemampuan Motorik Halusberdasarkan Anak keberapa di Yayasan Puteri Sion Medan Tahun 2017

\begin{tabular}{|c|c|c|c|c|c|c|c|c|c|c|c|c|}
\hline \multirow{3}{*}{ Anak keberapa } & \multicolumn{10}{|c|}{ Kemampuan Motorik Halus } & \multirow{2}{*}{\multicolumn{2}{|c|}{ Total }} \\
\hline & \multicolumn{2}{|c|}{ Lebih } & \multicolumn{2}{|c|}{ Normal } & \multicolumn{2}{|c|}{ Peringatan } & \multicolumn{2}{|c|}{ Keterlambatan } & \multicolumn{2}{|c|}{ TAK } & & \\
\hline & $\mathrm{n}$ & $\%$ & $\mathrm{n}$ & $\%$ & $\mathrm{n}$ & $\%$ & $\mathrm{n}$ & $\%$ & $\mathrm{n}$ & $\%$ & $\mathrm{~N}$ & $\%$ \\
\hline $\mathrm{I}$ & 1 & 5.3 & 8 & 42.1 & 4 & 21 & 2 & 10.5 & 0 & 0 & 15 & 78.9 \\
\hline II & 0 & 0 & 0 & 0 & 1 & 5.3 & 0 & 0 & 0 & 0 & 1 & 5.3 \\
\hline III & 0 & 0 & 1 & 5.3 & 0 & 0 & 0 & 0 & 1 & 5.3 & 2 & 10.5 \\
\hline IV & 0 & 0 & 0 & 0 & 0 & 0 & 0 & 0 & 1 & 5.3 & 1 & 5.3 \\
\hline Total & 1 & 5.3 & 9 & 47.4 & 5 & 26.3 & 2 & 10.5 & 2 & 10.5 & 19 & 100 \\
\hline
\end{tabular}

Sebanyak 15 (78.9\%) responden dari 19 responden (100\%) merupakan anak pertama dalam keluarga, 8 (42.1\%) diantaranya memiliki kemampuan motorik halus normal, 4 responden (21\%) peringatan, 2 responden (10.5\%) keterlambatan dan 1 responden (5.3\%) kemampuan lebih.

Tabel 6 Kemampuan Motorik Halus sebelum dan setelah dilakukan finger painting di Yayasan Puteri Sion Medan Tahun 2017

\begin{tabular}{lccccc}
\hline No & Kategori & \multicolumn{2}{c}{ Pre tes } & \multicolumn{2}{c}{ Post tes } \\
\cline { 3 - 6 } & kemampuan & $\mathrm{n}$ & $\%$ & $\mathrm{n}$ & $\%$ \\
\hline 1. & Lebih & 1 & 5.3 & 11 & 57.9 \\
2. & Normal & 9 & 47.4 & 6 & 31.6 \\
3. & Peringatan & 5 & 26.3 & 0 & 0 \\
4. & Keterlambatan & 2 & 10.5 & 0 & 0 \\
5. & TAK & 2 & 10.5 & 2 & 10.5 \\
\hline & Total & 19 & 100 & 19 & 100 \\
\hline
\end{tabular}

Kemampuan motorik halus anak sebelum dan sesudah dilakukan finger paintingmengalami peningkatan dimana sebelum bermain sebanyak 2 responden (10.5\%) pada kategori keterlambatan dan 5 responden (26.3\%) pada kelompok peringatan, sedangkan setelah bermain finger painting, tidak terdapat anak pada kelompok peringatan dan keterlambatan. Sebelum bermain finger painting, terdapat 1 responden (5.3\%) dengan kemampuan lebih sedangkan setelah finger painting meningkat menjadi 11 responden (57.9\%).
Tabel 7 Perbedaan kemampuan motorik halussebelum dan setelah intervensi bercerita dengan gambar di Yayasan Puteri Sion Medan Tahun 2017

\begin{tabular}{cccc}
\hline $\begin{array}{c}\text { Kemampuan } \\
\text { bahasa }\end{array}$ & Mean & SD & P Value \\
\hline $\begin{array}{c}\text { Sebelum finger } \\
\text { painting }\end{array}$ & 2.73 & 0.25 & \\
$\begin{array}{c}\text { Setelah finger } \\
\text { painting }\end{array}$ & 5.15 & 0.54 & 0.004 \\
\hline
\end{tabular}

Tabel 7. menunjukkan terjadi peningkatan kemampuan motorik halussebesar 0,29 kali lebih baik setelah diberikan intervensi bermain finger painting. Disimpulkan bahwa adanya Terdapat pengaruh bermain finger painting terhadap kemampuan bahasa karena $\mathrm{P}$ Value $=0.004$ atau $\mathrm{P}$ Value $<0,05$

\section{PEMBAHASAN}

Finger painting merupakan kegiatan melukis dengan jari yang dilakukan dengan cara menggoreskan pewarna secara langsung dengan jari tangan, telapak tangan secara bebas diatas kertas karena anak dapat mengeksplorasi ide-ide bebas untuk mengembangkan keterampilan motorik halusnya (Andrimeda freni, 2012). Melukis degan jari merupakan pengalaman yang menarik, dan kegiatan mengesankan bagi setiap anak. Keterampilan motorik halus melibatkan jari jari tangan serta koordinasi mata dan tangan, misalnya melukis, menggambar (Dwi S, 2015). Budi, U (2010) Hubungan motorik halus terhadap kecerdasan dipengaruhi oleh aspek perkembangan terutama dengan kaitan fisik dan intelektual anak terutama 
pada usia 3-5 tahun, semakin diberi stimulasi pada anak semakin cepatlah perkembangan motorik halus anak. Anak yang mampu mempelajari dan menguasai kemampuan motorik halus akan mampu melakukan segala sesuatu terutama mengkoordinasikan otot-otot kecil seperti; menyusun balok, melukis,menggerakkan jari terutama dalam mengoordinasikan tangan.

Hasil penelitian pada Tabel 4.1 menunjukkan bahwa kemampuan motorik halus anak sebelum finger painting,kategori Normal sebanyak 9 orang (47.4\%), Peringatan sebanyak 5 orang (26.3\%), Lebih 1 0rang (5.3\%), Terlambat sebanyak 2 orang (10.5\%) dan Tidak Ada Kesempatan (TAK) sebanyak 2 orang (10.5\%). Kemampuan motorik halus setelah dilakukannya finger painting terdapat kategori Lebih sebanyak 11 orang (57.9\%), Normal sebanyak 6 orang (31.6\%) dan TAK sebanyak 2 orang (10.5\%). Tabel 4.2 diketahui sebanyak 5 anak (26.3\%) pada usia gestasi 38 minggu. Soetjiningsih (2015), bahwa lahir cepat dari kelahiran normal akan mempengaruhi pertumbuhan dan perkembangannya. Anak yang lahir prematur akan mengalami keterlambatan dibandingkan anak normal. Tabel 4.2 terdapat1 responden (5.3\%) umur 4 tahun 3 bulan dan 1 responden (5.3\%) umur 4 tahun 6 bulan memiliki kemampuan motorik halus pada kelompok keterlambatan. Mayoritas responden berada pada kelompok umur 4 tahun 3 bulan dengan kemampuan motorik halus normal sebanyak 3 responden (15.9\%). Pada kelompok umur 4 tahun 6 bulan terdapat 1 responden (5.3\%) memiliki kemampuan motorik halus lebih.

Tabel 3. dari 19 responden, 9 responden berjenis kelamin laki-laki mayoritas 6 responden (31.6\%) memiliki kemampuan motorik halus normal dan dari 10 responden berjenis kelamin perempuan mayoritas memiliki kemampuan motorik halus peringatan sebanyak 4 responden (21.1\%). Sebanyak 1 responden (5.3\%) berjenis kelamin laki-laki dengan kemampuan motorik halus lebih sedangkan sebanyak 2 responden perempuan (10.5\%) memiliki kemampuan motorik halus keterlambatan.

Tabel 4. Setelah dilakukan finger painting sebanyak 7 responden laki-laki (36.8\%) memiliki kemampuan motorik halus lebih sedangkan pada responden perempuan, 4 responden (21.1\%) memiliki kemampuan motorik halus lebih dan 5 responden (26.3\%) dengan kemampuan motorik halus normal

Tabel 5. Sebanyak 15 (78.9\%) responden dari 19 responden (100\%) merupakan anak pertama dalam keluarga, 8 (42.1\%) diantaranya memiliki kemampuan motorik halus normal, 4 responden (21\%) peringatan, 2 responden (10.5\%) keterlambatan dan 1 responden (5.3\%) kemampuan lebih.

Tabel 6.Kemampuan motorik halus anak sebelum dan sesudah dilakukan finger paintingmengalami peningkatan dimana sebelum bermain sebanyak 2 responden (10.5\%) pada kategori keterlambatan dan 5 responden (26.3\%) pada kelompok peringatan, sedangkan setelah bermain finger painting, tidak terdapat anak pada kelompok peringatan dan keterlambatan. Sebelum bermain finger painting, terdapat 1 responden (5.3\%) dengan kemampuan lebih sedangkan setelah finger painting meningkat menjadi 11 responden (57.9\%).

Tabel 7. menunjukkan terjadi peningkatan kemampuan motorik halussebesar 0,29 kali lebih baik setelah diberikan intervensi bermain finger painting. Disimpulkan bahwa adanya Terdapat pengaruh bermain finger painting terhadap kemampuan bahasa karena $\mathrm{P}$ Value $=0.004$ atau $\mathrm{P}$ Value $<0,05$.

Berdasarkan tabel 4.7 dapat diketahui bahwa kemampuan motorik halus anak sebelum dan sesudah dilakukan finger painting dari 19 responden mengalami peningkatan yaitu sebelum finger painting kemampuan lebih sebanyak 1 orang (5.3\%), kemampuan normal sebanyak 9 orang (47.4\%), kemampuan peringatan sebanyak 5 orang (26.3\%), kemampuan keterlambatan sebanyak 2 orang (10.5\%) dan TAK sebanyak 2 orang (10.5\%) dan setelah finger painting kemampuan lebih sebanyak 11 orang (57.9\%), kemampuan normal sebanyak 6 orang (31.6\%), tidak terdapat kemampuan peringatan dan keterlambatan dan TAK sebanyak 2 orang (10.5\%). Vitamami (2012) bahwa finger painting dapat meningkatkan kemampuan motorik halus anak dengan hasil peneliti yaitu $80 \%$.

Berdasarkan Tabel 4.8 dapat diketahui bahwa anak berjenis kelamin laki-laki sebanyak 9 orang (47.4\%) dan perempuan sebanyak 10 anak (52.6\%) dan yang mengalami keterlambatan sebelum finger painting kategori keterlambatan terdapat 2 orang (10.5\%) berjenis kelamin perempuan. Sejalan dengan penelitian (Andrimeda freni, 2012) bahwa anak perempuan lebih dini dalam kecerdasan motorik halus terutama dalam kecekatannya.

Berdasarkan tabel 4.9 setelah finger painting pada kemampuan kategori lebih terdapat berjenis kelamin laki-laki sebanyak 11 orang (57.9\%), kategori normal sebanyak 6 orang (31.6\%), tidak ada kategori peringatan dan keterlambatan, dan TAK sebanyak 2 orang (10\%). Peneliti dapat menyimpulkan bahwa ada pengaruh finger painting terhadap perkembangan motorik halus berdasarkan anak pertama.

Hasil analisis penelitian menunjukkan bahwa terjadi peningkatan kemampuan motorik halus 2.42 kali lebih baik dibandingkan sebelum diberi intervensi finger painting. Dapat disimpulkan bahwa adanya pengaruh finger painting terhadap kemampuan motorik halus karena $\mathrm{P}$ Value $=0.004$ atau $\mathrm{P}$ Value $<0,05$. Berdasarkan hasil analisis data penelitian secara keseluruhan, dapat disimpulkan adanya pengaruh finger painting terhadap perkembangan motorik halus anak di Yayasan Puteri Sion Medan tahun 2017. Hal ini sejalan dengan dengan hasil penelitian para peneliti antara lain: 1. Andrimeda freda (2012) yang meneliti tentang pengaruh finger painting terhadap perkembangan keterampilan motorik halus anak kelompok B di TK pembangunan DSN. Lawan DS. Kedungwangi. Kec sambing. Kab lamongan. Hasil analisis menunjukkan bahwa terdapat perbedaan perkembangan motorik halus anak sebelum dilakukan finger painting sebanyak 14,5\% dan setelah melakukan finger painting sebanyak 20.4\%. 
Hal ini menunjukkan bahwa terdapat perbedaan kemampuan motorik halus anak sebelum mendapatkan kegiatan finger painting dan setelah mendapatkan kegiatan finger painting.

2. Askandari laila, dkk (2013) meneliti tentang pengaruh peningkatan motorik halus melalui pembelajaran finger painting pada anak usia 3-6 tahun. Hasil penelitian pada pertemuan pertama hasilnya sebanyak 53.5\% pertemuan kedua sebanyak $67 \%$ dan pertemuan ketiga sebanyak 73.3\% maka dapat disebutkan bahwa ada pengaruh finger painting terhadap perkembangan motorik halus anak.

3. Astria nina (2012) meneliti tentang pengaruh penerapan metode bermain finger painting untuk peningkatan motorik halus anak berdasarkan hasil analisis penerapan finger painting diperoleh hasil penelitian motorik halus pada pertemuan pertama sebesar 65,95\% dan perkembangan motorik halus pertemuan kedua sebesar 82,93\% berdasarkan hasil penelitian dapat membuktikan bahwa dengan penerapan finger painting dapat meningkatkan perkembangan motorik halus anak.

Dari beberapa teori dan penelitian diatas ternyata sejalan dengan hasil yang dilakukan oleh peneliti, bahwa finger painting berpengaruh terhadap perkembangan motorik halus pada anak 3-5 tahun.

\section{KESIMPULAN}

1. Usia gestasi berpengaruh terhadap kemampuan perkembangan bahasa anak, dimana anak dengan usia gestasi $\leq 36$ minggu mengalami keterlambatan perkembangan bahasa dibandingkan dengan anak dengan kehamilan 37-42 minggu.

2. Adanya pengaruh sebelum dan sesudah bercerita dengan gambar terhadap kemampuan bahasa anak berdasarkan umur perkembangan, dimana sebelum intervensi kategori keterlambatan ada sebanyak 3 anak sedangkan setelah intervensi kategori lebih dan normal meningkat, kategori peringatan berkurang dan keterlambatan tidak ada

3. Adanya pengaruh bercerita dengan gambar terhadap kemampuan perkembangan bahasa anak berdasarkan jenis kelamin dimana anak perempuan memiliki kemampuan bahasa yang lebih baik dibandingkan anak laki-laki.

4. Adanya peningkatan kemampuan bahasa setelah dilakukan intervensi bercerita dengan gambar dengan rata-rata peningkatan 0.76 kali lebih baik setelah diberikan intervensi.

5. Hasil uji statistik t-test menunjukkan kemampuan bahasa sesudah dilakukan intervensi bercerita dengan gambar berbeda secara signifikan yaitu nilai $\mathrm{P}$ value $<0,05$ yang artinya bahwa Ho ditolak dan Ha diterima. Sehingga dapat dinyatakan bahwa pelaksanaan bercerita dengan gambar dapat memberikan pengaruh terhadap kemampuan bahasa anak umur 3-5 tahun.

\section{SARAN}

Diharapkan kepada guru-guru di Yayasan Puteri Sion Medan memberikan tindakan bercerita dengan gambar untuk meningkatkan kemampuan bahasa dan perbendaharaan kata pada anak.

\section{DAFTAR PUSTAKA}

Cahyaningsih,S,D., (2014). Pertumbuhan Perkembangan Anak dan Remaja. Jakarta: CV.Trans Info Media.

Daulay S,. (2012). Pemerolehan \& Pembelajaran Bahasa. Bandung: Citapustaka Media Perintis.

Depkes RI, (2006). Pedoman Pelaksanaan Stimulasi, Deteksi Dan Intervensi Dini Tumbuh Kembang Anak Ditingkat Pelayanan Kesehatan Dasar. Jakarta.

Dewi,C,R, dkk, ( 2015). Teori \& Konsep Tumbuh Kembang Bayi, Toddler, Anak dan Usia Remaja. Yogyakarta: Nuha Medika.

Dewi dan Ennes (2015) STIKES RS. Baptis Kediri Jl. Mayjed. Panjaitan No. 3B Kediri. Faktor Kesehatan, Intelegensi, Dan Jenis Kelamin Mempengaruhi Gangguan Perkembangan Bahasa Anak Prasekolah.

Laily,L,I., dkk, (2014). Universitas Negeri Surabaya. Pengaruh Metode Cerita Bermedia Gambar Seri Terhadap Kemampuan Berbicara Anak Kelompok B Di TK Muslimat NU 38.Program Studi PGPAUD, Fakultas Ilmu Pendidkan.

Lilis dan Ati'ul (2014). STIKes Muhammadiyah Lamongan Program Studi S1 Keperawatan dan DIII Kebidanan. Peran Stimulasi Orang Tua Terhadap Perkembangan Bahasa Pada Anak Toddler diMayangkawis - Balen - Bojonegoro.

Kathryn, G, dkk. (2016) Konseling Anak- Anak Panduan Praktis. Jakarta : Indeks

Maryunani A., (2010). Ilmu Kesehatan Anak Dalam Kebidanan. Jakarta: CV.Trans Info Media.

Meity,I,H.,( 2014). Meningkatkan Kecerdasan Anak Melalui Dongeng. Jakarta: PT. Luxima Metro Media.

Notoatmodjo S., (2016). Metodologi Penelitian Kesehatan. Jakarta: PT Rineka Cipta.

Nugraha A,,S,M., dkk, (2014). Universitas Pendidikan Ganesha.Vol 4.Penggunaan Metode Bercerita Dengan Media Gambar Dalam Upaya Meningkatkan Kemampuan Berbahasa Dan Sikap Mandiri Anak Kelompok A TK Negeri Pembina Bangli Tahun Ajaran 2012/2013. E-Journal Program Pascasarjana Universitas Pendidikan Ganesha.Program Studi Pendidikan Dasar.

Nur dan Iswinarti (2016). Fakultas Psikologi, Universitas Muhammadiyah Malang.

Pengaruh Mendengarkan Dongeng Terhadap Kemampuan Bahasa Pada Anak Prasekolah di PAUD/KB Bunda Aini Malang.

Nursalam., dkk, ( 2008). Asuhan Keperawatan Bayi dan Anak (untuk perawat dan bidan). Jakarta: Salemba Medika. 
Rachmawati Y., dkk, (2011). Strategi Pengembangan Kreativitas Pada Anak Usia Taman Kanak-kanak Edisi kedua. Jakarta: Prenada Media Group.

Sardi, dkk (2015). Program Studi Pendidikan Dasar, Program Pascasarjana Universitas Pendidikan Ganesha Singaraja, Indonesia. Pengaruh Pembelajaran Dengan Teknik Bercerita Dongeng Terhadap Kemampuan Berbahasa Dan Motivasi Anak Kelompok B TK Kunti II Dalung.

Sari Meliana, (2015). Universitas Pendidikan Indonesia Program Studi PG-PAUD. Meningkatkan Pemahaman Orang Tua Dalam Menstimulasi Perkembangan Bahasa Anak Usia Dini Melalui Program Parenting.

Soetjiningsih., dkk, (2015). Tumbuh Kembang Anak edisi kedua. Jakarta: Buku Kedokteran. EGC.

Sulistyawati A., (2014). Deteksi Tumbuh Kembang Anak. Jakarta: Salemba Medika.

Suryadi., (2009).Ternyata Anakku BisaKu Buat Genius. Jogjakarta : Power Books (Ihdina).

Tehupeiory Marlen., dkk, (2014). Universitas Pendidikan Ganesha. Vol.2. No. 1. Penerapan Metode
Bercerita Menggunakan Media Gambar Untuk Meningkatkan Kemampuan Berbahasa Anak Kelompok B Semester II. e-Journal PG-PAUD.

Tim Preschool Online., (2015). Serunya Dunia Anak Usia Dini. Jakarta : Panda Media.

Utami,W,S., dkk (2014). STIKES 'Aisyiyah Yogyakarta Program Studi Keperawatan. Pengaruh Metode Bercerita Dengan Gambar Terhadap Perkembangan Bahasa Anak Usia 3-5 Tahun Di Paud Sariharjo Ngaglik Sleman. 